\title{
Evolution-by the (Text) Book
}

\author{
Kenneth R. Miller
}

Published online: 16 April 2010

(C) Springer Science+Business Media, LLC 2010
But something funny happened on the way to a scientific career. As I worked my way through graduate school I discovered something unexpected. I realized that I liked to teach. It was almost accidental. As a graduate teaching assistant, for the first time I found myself in the position of trying to explain difficult material to students who didn't quite get it. What I then experienced was a sensation common to all teachers - the absolute delight of seeing a struggling student "get it" for the first time. It is, almost literally, like watching a light go on in a darkened room. I realized, for the first time, that I wanted to be in academic science, so I could teach as well as to do research. In 1981, that led directly to what one might call two "invitations" to step a bit outside my research field of cell biology.

\section{Two Invitations}

Near the middle of my first year on the faculty at Brown University, a group of students walked into my lab, explaining that they had enjoyed my fall term lectures in their first year biology class. Nice enough to hear, but they'd come there for another reason. They challenged me to debate Dr. Henry Morris, of the Institute for Creation Research, who was coming to campus in April. I thought it would be fun, a one-time thing, and I agreed. I spent the next five weeks steeping myself in creationist literature, listening to audio tapes of Morris and his comrade Duane Gish, and preparing $35-\mathrm{mm}$ slides to illustrate the scientific points I planned to make. Determined not to allow my opponent an opening, I researched one argument after another, doing my best to become an instant expert on moon dust accumulation, rubidium-strontium dating, ${ }^{14} \mathrm{C}$ in mollusk shells, the ebb and flow of earth's magnetic field, and sea urchin paleontology. Although I knew why I had to
K. R. Miller $(\bowtie)$

Department of Molecular Biology, Cell Biology, \& Biochemistry,

Brown University,

Providence, RI 02912, USA

e-mail: Kenneth_Miller@Brown.edu 
delve into these subjects-they are all used as arguments against evolution-I thought I'd never use these bits of knowledge again. I couldn't have been more wrong.

By the time the debate took place (see Fig. 1), on April 10, 1981, I was prepared for Morris. But I was not prepared for the intensity of public interest in the issue. Nearly two thousand people attended, motivated in part by recently enacted creationist laws in Arkansas and Louisiana. Many, quite frankly, wanted to see if "creation science" was the wave of the future. When the debate was over, it was clear that most were pretty well convinced that it wasn't.

Not long after that debate, I was invited to spar with Morris again, this time in Tampa, Florida, whose school board had just approved a new biology curriculum that included "creation science." As I prepared to leave for Tampa, I got a phone call from Joe Levine, whom I remembered as a grad student in my electron microscopy

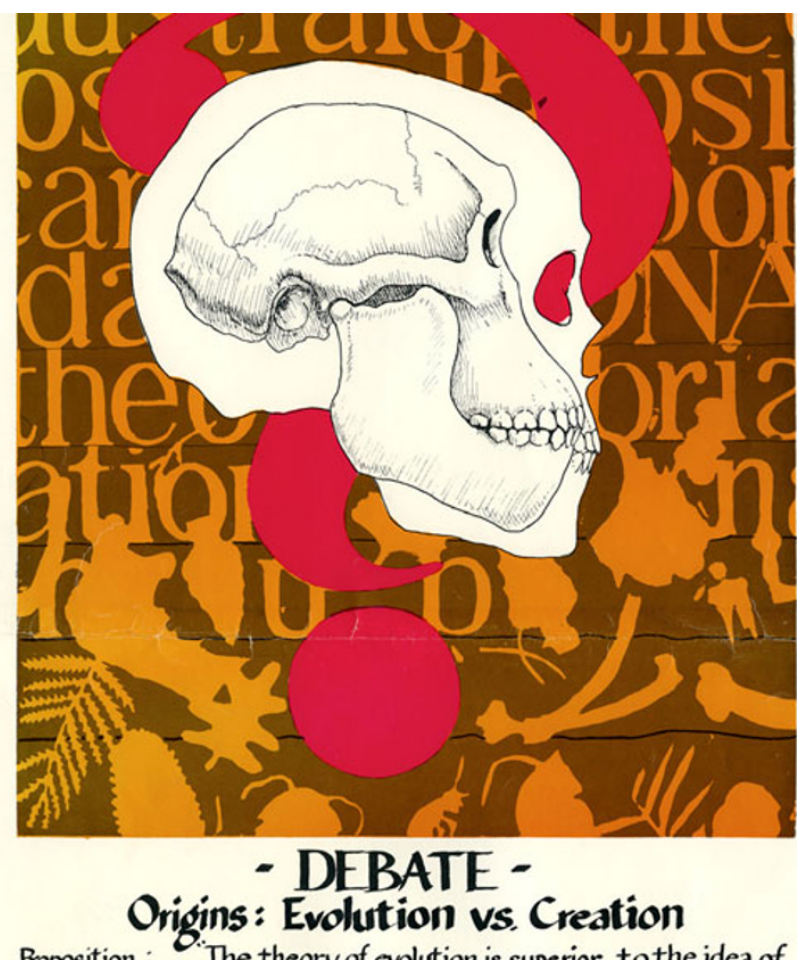

Froposition : ... The theory of evolution is superior to the idea of special creation as an explanation for the scientific evidence AfFRMative: related to origins." NEGATIve: Dr. Kenneth Miller, related to origins. Dr. Henry Morris, dir.
Brown U. Dept. of Biology. of the Institute for Creation Friday. April $10 \%$ pm. Meehan Aud. fru with, Brown To, California.

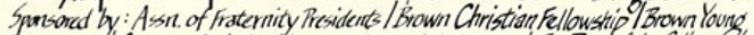

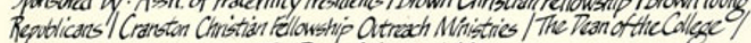
The Tean of Student Life

Fig. 1 Poster announcing a 1981 debate between Henry Morris of the Institute for Creation Research and Kenneth Miller of Brown University. Preparation for this debate provided the author with an extensive introduction to the arguments used against evolution course at Harvard. Joe had finished his Ph.D. and had just taken an assistant professorship at Boston College. Good to know, of course, but why was he calling? I found out soon enough. Joe's writing skills had been noticed. He had been approached by an editor and persuaded to become the author of a new high school biology textbook. How did that concern me, I wondered. Well, Joe wanted me to join him as coauthor, merging my expertise in cellular and molecular biology to his in evolutionary biology and ecology.

At first, I turned him down. I was only a year away from a tenure decision and had no desire to complicate the minds of our promotions committee with anything other than a list of grants generously funded and papers published in proper journals. But Joe soon carried the day, reminding me of my passion for the classroom and holding out the prospect of our being in a thousand classrooms, every day, by virtue of our imagined textbook. What then followed were eight long years of writing, contract negotiations, more than a few lessons in corporate restructuring, rewriting, switching publishers, and finally, in 1990, a first look at our brand new text.

\section{Storytelling}

Joe and I had always believed that all great teachers were, in essence, storytellers. To our minds, the problems with so many biology textbooks, including the ones we had used in school, is that they didn't tell much of a story. They gave students lists of terms to memorize, described anatomies, behaviors, and biochemical pathways, but not once did they hint that this stuff might actually be interesting, that there were stories behind these discoveries, or, most importantly, that there were great discoveries still to come. We resolved that we were going to be different.

We personalized science, telling students the stories of Alexander Fleming, Rosalind Franklin, and Gregor Mendel. We hinted at things to come, including the possibility that the Archea would someday be recognized as a sixth great kingdom of life (which, of course, they soon were). Joe crafted an extraordinary evolutionary narrative, presenting evolutionary theory through a chronicle of Darwin's physical and mental journeys. And, above all, we emphasized that biology was not a finished science. It contains great mysteries, which would remain for the next generation of scientists, our student-readers, to solve. Having finished our manuscript, we had no idea what would come next. We'd told our story, and we figured it was up to the publisher to do what publishers do best, namely, to market the new book. Little did we know that we were both about to get an education in the practical politics of textbook publishing, an education for which my debates with creationists would prove invaluable. 


\section{Conflict}

Within a few weeks of its appearance in the Spring of 1990, our new book was presented for approval to the Texas State Board of Education. Our publisher was kind enough to ask me if I'd like to sit in on the public hearings for the book, and I jumped at the chance to spend a couple of quiet days in Austin, one of my favorite cities. I still love Austin, but the hearings were anything but quiet. I had done a little advance reading on the textbook approval process in the Lone Star State, and two names that came up time and time again were Mel and Norma Gabler. Almost single-handedly they had developed enough influence among Board members to force publishers to rewrite textbooks to their liking, and I wondered if they would do the same to biology books.

As I entered the hearing room for the first time, someone grabbed the hand of the person following me and loudly proclaimed how happy he was to see "Mr. Gabler" that morning. Taking a salutatory cue, I turned around and introduced myself to Mel Gabler, let him know that I'd been reading about him, and that it was a pleasure to meet him in person. It surely was. It was also a pleasure to watch him work. Public comment was limited to just a few minutes per person, but Gabler showed that he knew how to make good use of that time. As he stood up, he unrolled a large scroll which he described as a list of "errors in evolution." $\mathrm{He}$ read the first few quickly, claimed that all of the textbooks up for consideration contained such errors and then made an impassioned plea for the Board to protect the schoolchildren of Texas. "Good science," according to Gabler, viewed evolution as unsupported speculation. And good science is what we should have in our classrooms. Brief, powerful, and to the point.

Then and there, I started scribbling a list of responses to each of the supposed "errors" of evolution in our new book. Immediately I realized that my time used in preparation for debates had been very well spent. The very same arguments raised by Morris in 1981 were now being used against our book, nearly a decade later. By the time I was done, we had the framework of a written point-by-point response to such criticisms. Joe and I would circulate a document with those responses throughout the state during the adoption campaign. But the Gablers were not alone. One citizen used his allotted time merely to read aloud from the Bible, and then quietly asked for God's help to correct these awful textbooks. Another attacked our chapter on "Alcohol and Other Drugs," worrying that a single sentence describing the "sense of euphoria" induced by marijuana would produce thousands of pot-smoking schoolkids eager to get the same high we had "promised" them in our textbook.

What I realized, by the time my three days in Austin were over, was that writing a biology textbook had turned out to be much more than a wide-eyed exercise in storytelling. It wasn't going to be enough just to turn kids on to biology. We were going to have to defend the process of science itself against people who believed, with all their hearts, that we had only the worst of intentions for them and for their children. To the Gablers and many of those who followed them to Austin, this was war - and we were the enemy.

\section{Enter the NCSE}

In truth, I should have known that this would happen. Back in 1981, as word of my first debate with Morris got around, I had been invited to Des Moines, Iowa, by the late Stanley Weinberg. At the time, Weinberg had organized a group called the "Committees of Correspondence" to combat what seemed to be an ever-rising tide of creationism across the United States. The local school board in Des Moines was considering whether to mandate the teaching of creation science, and Stan thought that I might help persuade them otherwise. During the visit, Stan gave me a copy of his own high school biology textbook, copyright 1974, and asked if I might like to become his coauthor for a new revision. I had turned him down - Stan wasn't nearly as persuasive on this point as Joe Levine would turn out to be - but Stan remarked that he could understand why a young professor wouldn't want to get involved in the controversy associated with textbooks. By 1990, happily, such worries had almost faded away. All I needed were a few days in Austin, and the memory of these issues came roaring back.

Earlier, Stan's work with the Committees of Correspondence had led to the founding of the National Center for Science Education (NCSE), which was incorporated in 1983. In their search for a professional leader, the fledgling organization turned to a young anthropologist who had led the fight to keep creationism out of the public schools in Lexington, Kentucky. Her name was Eugenie Scott. Scott quickly took the work of the new organization to a new level, establishing a permanent office, hiring full-time staff, and coordinating the efforts of volunteers throughout the country. By the time of the Texas hearings, Genie was fully engaged in textbook battles in several states, including Texas. Her presence in Austin, as well as the tireless work of the NCSE organization, helped to strengthen the resolve of publishers and authors, ourselves included, to stand firm on the issue of evolution.

None of this came easy. We faced persistent pressure from editorial and sales personnel to limit or deemphasize our coverage of evolution in advance of state hearings. The authors of a competing text added a paragraph on creation, placing pressure on us to follow suit. And at least one biologist coauthor of a competing book refused to sign a letter of solidarity on the evolution issue, a letter we had 
drafted and which all other authors had endorsed. Fortunately, we managed to resist such pressures, as did most authors. The result, to the frustration of the anti-evolution movement, was an approved list of textbooks, including ours, with strong, up-to-date treatments of evolution.

Two subsequent cycles of textbook adoptions in the state have continued this pattern, despite determined attempts to introduce "intelligent design" (ID) and other creationist critiques into science textbooks. In 2003, for example, the Texas Board of Education insisted that biology textbooks highlight the "strengths and weaknesses" of scientific theories and hypotheses, including evolution. Rather than weaken the treatment of evolution in our textbook, Joe Levine and I decided to simply write a new heading over an existing paragraph describing the practical uses of evolutionary theory as well as a number of unsolved scientific issues. This left the content of our description of evolution unchanged, but met the literal requirement of the Texas standards. In so doing, we hoped to deprive the Board of any reason to argue that our book did not meet Texas standards, while still preserving what we regarded as the strongest treatment of evolution in any high school text. Happily, other authors and publishers have also held the line, and the textbooks used in Texas high schools today uniformly present evolution as reflecting the scientific consensus at the heart of the science of biology (see Bhattacharjee 2009, for a summary of recent events in Texas).

Texas, however, is only one state among many in which these battles have taken place. Biology textbooks have been attacked in states east and west, from Hawaii to Florida, and north and south, from Mississippi to Alaska. In some cases, boards of education have demanded that sections on evolution be rewritten. In others, they have attached warning labels to books to tell students that evolution is "a theory, not a fact," as shown in Fig. 2. In 2004, a group of parents led by Jeffrey Selman filed suit against the Cobb County, Georgia, School Board, leading to a federal trial on the constitutionality of such stickers (Holden 2002, 2005). The Federal District Court in Atlanta found for the plaintiffs in that case and ordered the stickers removed from
Fig. 2 The evolution warning sticker placed on biology textbooks by the school board of Cobb County, Georgia, in 2002. The stickers were eventually removed as the result of a First Amendment lawsuit, Selman v. Cobb County Board of Education (Holden 2005)

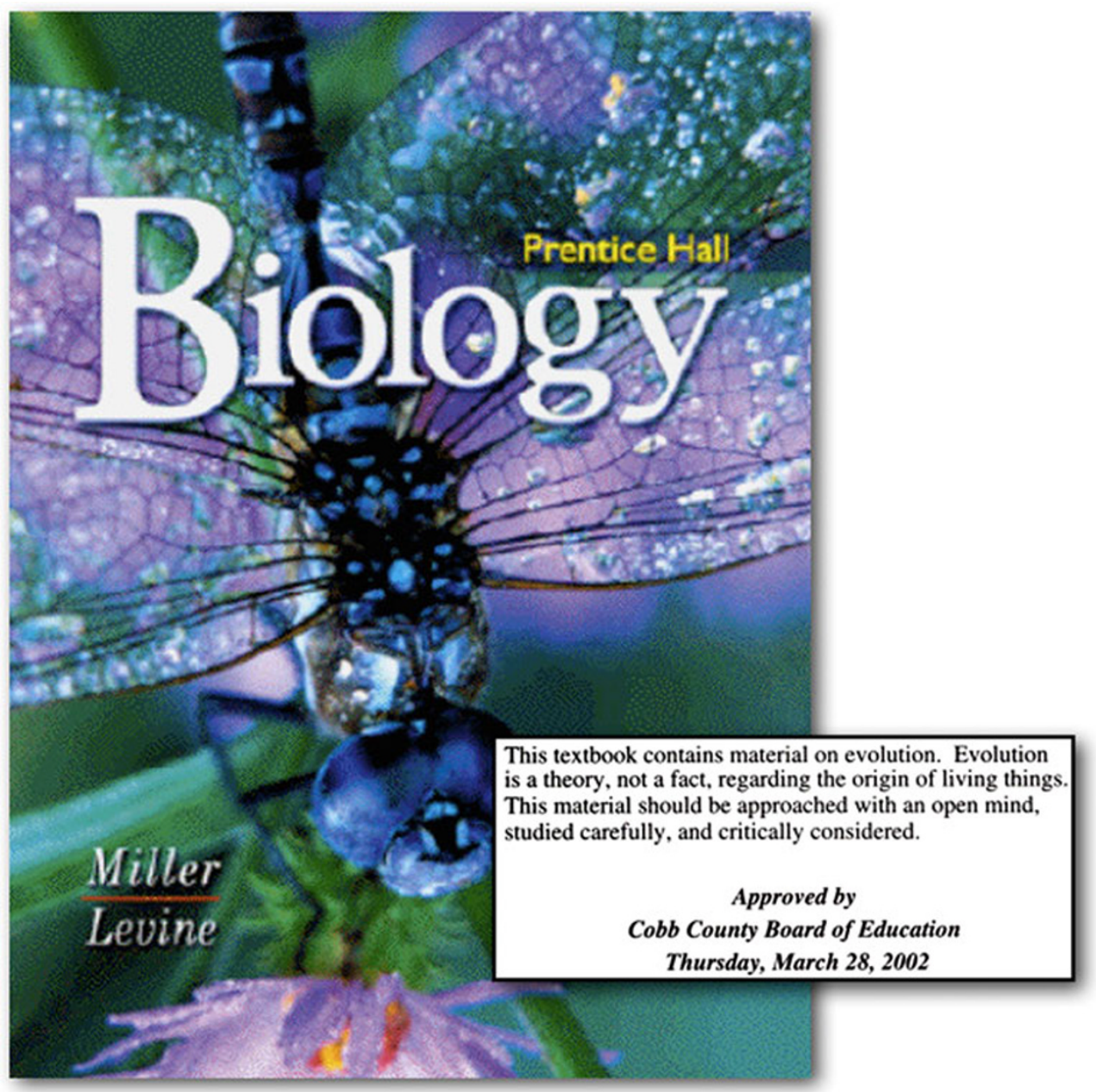


textbooks. After an appeal to the Federal Circuit Court, an agreement between the plaintiffs and the Cobb County School Board resulted in the permanent removal of the stickers. In each case, the nationwide efforts of the NCSE, mobilizing scientists, educators, health professionals, and concerned citizens, have been central to safeguarding the integrity of science education.

\section{Why Textbooks?}

Our own work as authors notwithstanding, when Joe Levine and I speak to teachers, we often try to put the role of any textbook into its proper context. If I were asked as a parent, for example, whether I would prefer my own children to study with the poorest teacher using the best textbook, or with the best teacher using a poor textbook, there is no question I would choose the latter. A science textbook, even the best one, is no substitute for a great teacher, and teachers are by far the most important components of a quality science education.

Yet, it is worth noting, as a case in point, that textbooks were indeed the spark that ignited the landmark Kitzmiller v. Dover intelligent design trial in 2005. A member of the Dover, Pennsylvania, Board of Education objected to the science teachers' choice for biology textbooks (ironically, the one written by Joe Levine and myself) by asserting that the book was "laced with Darwinism" from cover to cover. The same Board then accepted a donation from the community to purchase 60 copies of an "intelligent design" textbook called Of Pandas and People. Once these books were placed in the high school library, the Board drafted a statement on ID that was read to biology students over their teachers' objections (Mervis 2005a). What followed was a seven-week trial on the issue of ID in the science classroom, and once again Eugenie Scott and her colleagues at the NCSE played a key role. Genie and NCSE staffer Nick Matzke attended every day of the trial, helped to develop both legal and scientific strategy, and served as invaluable resources to the plaintiffs and their legal team. Despite the success of that effort, and the judge's ringing decision against the School Board (Mervis 2005b), it is only fair to ask why textbooks continue to gather such attention in our culture wars? Why is so much effort expended in the public ritual of attack-and-defend each time a biology textbook comes up for approval in certain states?

I think the answer is simple. Textbooks are at once the most visible part of any curriculum, but they are also the parts that individual citizens feel least able to affect on a local level. You can always have a talk to your son's or daughter's biology teacher and hope to influence their teaching. As a citizen, you might be able to influence educational policy in your own school district or even in your state. But textbooks are published by large, distant corporations, and many people perceive, sometimes correctly, that the only way to change them is by political action at the state level. In such a context, it makes perfect sense to organize and lobby, especially in larger states, in a way that applies pressure to publishers and authors.

Does this justify organized campaigns to insert youngearth creationism or ID into science textbooks? Not at all. But it does help to explain why such campaigns are common, and why political systems, including state boards of education, are receptive to them. The reason such campaigns must be resisted is not because they are improper in a democratic society. Rather, it is because the ideas they seek to insert into textbooks have failed as science and therefore have no place in science education. To make that case effectively, the scientific and educational communities must realize that consensus in the scientific community is not enough. A bumper harvest of experimental results, DNA sequences, and transitional fossils will not carry the day unless we, ourselves, are willing to stand publicly for the cause of science. Towards this end, the career of Genie Scott has been exemplary. Not only has she set a personal example of courage and scientific integrity, but her skillful and persuasive organizing have mobilized the efforts of scores of others and, not coincidentally, raised the bar for the coverage of evolution in biology textbooks.

The efforts of individuals such as Dr. Scott notwithstanding, at the end of the day, the scientific community itself must bear the burden of explaining science to the public. The success of the scientific enterprise depends upon it, and in today's society that means supporting the popularization of science and, where necessary, political action to bring the case for science to our elected officials. In many respects, teachers and scientists themselves are the ones that matter most. In the brutal language of market economics, teachers are the ultimate consumers of textbooks. By serving on textbook committees, by lobbying for more effective professional review of textbook content, and by demanding quality products from publishers, teachers can influence science textbooks for the better, and they can do so in dramatic ways. Their natural allies in this process should come from the scientific community. Yet all too often, professional researchers and university scientists have acted as though disinterested or even aloof from the concerns of science educators. In a nation that draws its scientific community from the halls of public schools, such neglect is nothing short of self-destructive. Attitudes like these must change, and professional scientific societies should take the first steps to assure that they do. By supporting - and even rewarding - the efforts of their members to support science education, our professional societies and associations can support their colleagues in 
the education community and help to ensure the health of the scientific enterprise for the future.

The content of science textbooks may seem like a small matter in a world where the pace of research drives those books to obsolescence so quickly. Textbooks are far from perfect, and we should work ceaselessly to improve them, but they nonetheless perform essential roles in our educational system. At their best, they present students with important lessons in the process of science, they illustrate the values of free inquiry, and they relate stories of men and women advancing our understanding of the natural world. Textbooks matter not only because they document and explain the scientific consensus, but because occasionally they open a window on the world of scientific discovery that lures the best and the brightest into a lifelong journey towards knowledge. We must do our best to ensure that window remains ever open.

\section{References}

Bhattacharjee Y. Authors scramble to make textbooks conform to Texas Science Standards. Science. 2009;324:1385.

Holden C. Georgia County opens door to creationism. Science. 2002;298:35-6.

Holden C. Judge orders stickers removed from Georgia textbooks. Science. 2005;307:334.

Mervis J. Dover teachers want no part of intelligent-design statement. Science. 2005a;307:505.

Mervis J. The Dover ID decision: Judge Jones defines science - and why intelligent design isn't. Science. 2005b;311:34. 